\title{
РОЛЬ ТЕХНОЛОГІЙ АВТОМАТИЗОВАНОГО ПРОЕКТУВАННЯ ТА ВИРОБНИЦТВА У ВПРОВАДЖЕННІ ПІДХОДІВ ІНДУСТРЇ̈ 4.0 В СФЕРІ ОХОРОНИ ЗДОРОВ'Я
}

\author{
Рудніцька О.В. доцент, $\mathrm{PhD}$ \\ olena.rudnitska@gmail.com \\ Факультет біомедичної інженерії \\ Національний технічний університет України \\ “Київський політехнічний інститут імені Ігоря Сікорського", \\ м. Київ, Україна
}

\begin{abstract}
Реферат - Дана робота розглядає способи застосування САD САМ технологій в сфері охорони здоров'я на шляху до переходу на засади парадигми Неalthcare 4.0 . Дані технології дозволяють досягати значних результатів в покращенні медичних послуг та проектуванні і виготовленні виробів медичного призначення. Для иього проаналізовано роль парадигми Індустрія 4.0 в сфері розвитку галузі охорони здоров'я, роль САD САМ технологій в медичній галузі та виділені тендениії розвитку САD/САМ технологій в контексті переходу до Healthcare 4.0.

При аналізі ролі парадигми Індустрія 4.0 було виділено основні групи технологій, щзо є рушійними силами цієї концепиї̈, та коротко описано технології, здатні підвищити рівень безпеки, задоволеності та інформованості для пацієнта: робототехніка, голографія, датчики/сенсори, інтернет речей та промисловий інтернет речей, великі дані, штучний інтелект та адитивне виробництво. При дослідженні ролі САD\САМ технологій в медичній галузі, було проаналізовано застосування ичих технологій в (а) хірургії та розглянуто напрялки комп'ютерно-інтегрованої хірургії (хірургічний CAD/САМ та хірургічний асистент) та ортопедичні операціі або операції по заміні суглобів; (б) використання технології САD/САМ в медичних пристроях; (в) використання технологї САD/САМ в діагностичних процедурах. Далі показано потенціал САD як засобу підвищення ефективності та впровадження інновацій. При аналізі сучасних тенденцій розвитку CAD/CAM технологій в контексті переходу до парадигми Неalthcare 4.0, було виділено та описано наступні аспекти: (1) посилення впливу хмарних технологій та перевагам, що він надає; (2) модельно-орієнтований підхід та особливості його застосування при автоматизованому проектуванні; (3) генеративне проектування із застосуванням технологій штучного інтелекту. Наведено переваги застосування штучного інтелекту в процесі проектування та виготовлення необхідних для медичної галузі продуктів та його можливий вплив на галузь в цілому.

Висновки: Технологія САD/САМ зробила значний вплив на прогрес у медичній науці та практиці. Потенціал САD як засобу підвищення ефективності та інновацій зростає, а останні тенденції галузі охорони здоров'я відображсають вплив нових технологій у цій галузі. Охорона здоров'я - сфера першочергового значення, до якої вкрай необхідне включення традиційних наукових галузей з інновачійними ріменнями. Наближення медичної галузі до парадигми Неalthcare 4.0 можливе, в тому числі, за допомогою вдосконалення CAD/CAM підходів та алгоритмів та розширюючи сфери застосування, тим самим досягаючи значних результатів в покращенні медичних послуг та підвищенні ефективності таких послуг, в тому числі і економічної. Тому вбачаються доцільними подальші дослідження щодо збільшення сфер застосування САD/САМ технологій та взагалі підходів парадигми Індустрії 4.0 в медичній галузі (Healthcare 4.0).
\end{abstract}

Ключові слова: САD САM, Індустрія 4.0, Hеalthcare 4.0, итучний інтелект, хмарні технологї, адитивне виробництво.

\section{I. ВСТУП}

В даний час весь світ переходить до четвертої промислової революції, або Промисловості 4.0 (Індустрія 4.0, Industry 4.0), що представляє собою концепцію переходу до цифрових, повністю автоматизованих середовищ та кіберфізичних систем. Сам термін відслідковується з листопада 2011 року в статті німецького уряду, де вони представили свою високотехнологічну стратегію під назвою
«Industry 4.0» [1]. Наразі Industry 4.0 містить багато різних технологій та інновацій, які впроваджуються у різних секторах багатьох країн [2]. Невід'ємною іiі складовою $€$ Healthcare 4.0 - галузь охорони здоров'я або медицини. На даний час існують різні тлумачення терміну «розумного здоров'я» або Smart Health, починаючи від «медичної практики та практики громадського здоров'я, що підтримується розумними мобільними пристроями (тобто смартфонами)» [3] або «інтелектуальне 
управління охороною здоров'я та медичні послуги 3 використанням інформаційних технологій» [4] до «використання таких технологій, як розумні мобільні телефони, смарт-картки, роботи, датчики та системи телемедицини через Інтернет на основі плати за використання за найкращі медичні практики» [5]. Натомість Healthcare 4.0 характеризується прийняттям трьох основних парадигм: Інтернету речей, Великих даних і Хмарних обчислень, які разом роблять революцію в сфері охорони здоров'я та всій його екосистемі, як i Індустрія 4.0 для виробничого сектора [6].

Вся екосистема охорони здоров'я наразі рухається у напрямку Healthcare 4.0, застосовуючи методології Промисловості 4.0, хоча слід зазначити, що окремі ii сегменти рухаються 3 різною швидкістю. Багато технічних та інноваційних підходів вплинули на перехід сектору до Парадигми 4.0, в тому числі

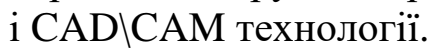

Використання інформаційних та проектних технологій, які полегшують зв'язок між фізичним та цифровим світом, дає можливість застосування засобів аналізу інформації для отримання взаємозв'язку між даними, співпраці між системами та фізичними пристроями, для створення так званої інтелектуальної промисловості або безпосередньої взаємодії 3 кінцевим споживачем, таким чином досягаючи оптимізації та взаємодії процесів досліджень та розробок, проектування, виробництва, логістики та надання послуг. Системи CAD (англ. Computer-aided design, технологія автоматизованого проектування) та САМ (англ. Computer-aided manufacturing, технологія автоматизованого виробництва) актуальні в цій новій революції, оскільки вони дозволять переробляти, моделювати та контролювати моделі, які будуть вироблятися, без зупинки виробничої лінії.

\section{ІІ. ОГЛЯД ЛІТЕРАТУРИ}

У цьому розділі ми розглянемо деяку літературу, яка зосереджена на Індустрії 4.0 та іiі потенціалі в медицині та медичному обслуговуванні відповідно до парадигми 4.0. Систематичне обстеження екосистеми електронного здоров'я разом із впливом на неї 3 боку Інтернету речей, технологій великих даних та хмарних обчислень було представлено у [7].
Інше дослідження [8] в основному зосереджувалося на Healthcare 4.0 та на тому, як вона походить від Індустрії 4.0. Відзначаючи широкий спектр технологій, що дозволяють Індустрії 4.0 та Healthcare 4.0 надавати більш ефективні та дієві послуги, автори використали методологію піраміди мудрості (Wisdom Pyramid Methodology). Вони провели систематичний огляд наявних нині цифрових технологій на передньому краї Healthcare 4.0.

Автори [9] досліджували існуючі тенденцій, проблем і теоретичних прогалин у впровадженні Healthcare 4.0 на основі огляду літератури. Їх результати показали, що розвиток Healthcare 4.0 іде міждисциплінарним шляхом, 3 різноманітними додатками та функціями. Також вони виявили, що елементи концепції Healthcare 4.0 найчастіше впроваджуються в управлінні лікарняною інформацією. Також були виявлені основні тенденції в цьому напрямку.

Автори огляду [10] порівнювали використання $\mathrm{CAD} / \mathrm{CAM}$ технологій в стоматології із традиційними відновними методами з точки зору безпеки, ефективності та економічної ефективності 3 використанням Кокранівської бібліотеки, CRD та Pub med. B результаті прийшли до висновків, що ці технології здаються безпечними та ефективними, і такими, що матимуть сприятливі результати 3 точки зору економічної ефективності.

Стаття [11] ілюструє тенденції розвитку, які призводять до сучасних концепцій охорони здоров'я з електронною підтримкою.

У роботі [12] автори демонструють широкі можливості Промисловості 4.0 для виробництва нових індивідуальних імплантатів та інноваційних інструментів та застосунків для медицини. Вони вважають, що Industry 4.0 - це інноваційний підхід до створення нової концепції та розвитку медичної галузі шляхом інтеграції технологій, розумних машин та різного програмного забезпечення. I, за їx думкою, у майбутньому Індустрія 4.0 може створити нові можливості та інноваційні шляхи догляду за пацієнтами.

\section{III. МЕТА ДОСЛІДЖЕННЯ:}

CAD/CAM технології являються важливою складовою адитивного виробництва, що є одним 3 флагманів Парадигми 4.0. Нажаль, існує недостатньо досліджень, за допомогою яких 
можна було б скласти цілісний погляд на ситуацію застосування CAD/CAM технологій у медичній галузі в контексті іï руху в бік Індустрії 4.0. Саме заповнення цієї прогалини і $\epsilon$ метою даної роботи.

Для вирішення поставленої задачі було проаналізовано чимало наукових досліджень та офіційних джерел методом сходження від абстрактного до конкретного та зроблені відповідні висновки. Використовуючи аксіоматичний метод, було констатовано, що поступ досліджуваних парадигм $\epsilon$ невідворотним і тому заслуговує досконального аналізу та вивчення. У цьому документі надається (iv) опис ролі парадигми Індустрії 4.0 в медичній галузі (v) опис впливу CAD/CAM технологій на розвиток медичних технологій (vi) аналіз сучасних тенденції розвитку $\mathrm{CAD} / \mathrm{CAM}$ технологій в контексті переходу медичної галузі до парадигми Healthcare 4.0.

\section{IV. РОЛЬ INDUSTRY 4.0. В МЕДИЧНІЙ ГАЛУЗІ.}

Зростання населення світу та зростаючі очікування щодо ефективного лікування та покращення якості життя загалом тиснуть на охорону здоров'я. Тому охорона здоров'я залишається однією 3 найважливіших соціальних та економічних проблем у всьому світі, що вимагає від науки і техніки нових $\mathrm{i}$ прогресивніших рішень [13] У відповідь на такі потреби з початку 1990-х років інформаційнокомунікаційні технології (IКТ) позитивно вплинули на доступ, ефективність та якість практично будь-якого процесу, пов'язаного 3 охороною здоров'я [14].

Елементи парадигми Індустрії 4.0 здатні допомогти у вирішенні різноманітних медичних проблем за допомогою міждисциплінарного підходу.

Передбачається, що елементи Індустрії 4.0 можуть виконувати такі функції в медичній галузі [15]:

- покращувати продуктивність;

- допомагати 3 аналізом даних пацієнта, які можуть бути корисними для різних медичних технологій;

- забезпечувати цифрове зберігання медичних даних та допомагати у виявлені наступного рівня захворювань;

- підвищувати точність;

- зменшувати витрати часу;
- поліпшувати якість;

- зменшувати потреби в ресурсах, зберігаючи і обробляючи дані пацієнтів у CAD системах;

- зменшувати паперову роботу;

- покращувати управління матеріалами;

- покращувати управління інструментами;

- ефективно виготовляти індивідуальні імплантати відповідно до потреб пацієнта, використовуючи інтелектуальні компоненти на основі сенсорів;

- застосовувати правильні процеси контролю для складних операцій;

- за допомогою сенсорної системи та цифрових технологій $\epsilon$ змога автоматично відстежувати нові захворювання;

- створити централізовану інформаційну систему в лікарні;

- визначати дані пацієнта та іншої відносної інформації.

Крім залучених технологій, фактично існують також плани розвитку, включаючи аспекти управління підприємством та організації роботи, нормативно-правову базу, а також розповсюдження та навчання. 3 суто технічної точки зору, ця так звана четверта промислова революція базується в основному на концепції кіберфізичних систем або CPS (cyber-physical systems), що являє собою інтеграцію обчислень, зв'язку та управління. Тобто ідея кіберфізичних систем полягає в тому, щоб інтегрувати інтелект у повсякденні об'єкти/послуги для виконання важливих завдань. Цю концепцію можна застосовувати до соціальних послуг, особливо в медицині та охороні здоров'я [16]. Підвид кіберфізичних систем - медичні кіберфізичні системи (Medical cyber-physical systems, MCPS) є критичною для охорони здоров'я інтеграцією мережі медичних пристроїв. Ці системи все частіше використовуються в лікарнях для забезпечення безперервної високоякісної медичної допомоги.

Загалом Індустрія 4.0 в значній мірі покладається на три групи технологій (основи):

- Інтернет речей (Internet of Things, IoT) характеризується повсюдною присутністю різноманітних однозначно адресованих взаємодіючих об'єктів, таких як мобільні телефони, датчики та приводи;

- Хмарні та туманні обчислення (Cloud and Fog Computing) - забезпечення практично необмежених обчислювальних, сховищ i 
комунікаційних ресурсів як утиліт, тобто на вимогу та з оплатою за використання;

- Аналітика великих даних (Big Data Analytics) - для отримання цінності зі складних обсягів даних [7].

Індустрія 4.0 допомагає впровадити цифровізацію в медичній сфері за допомогою різних технологій. Ці технології здатні підвищити рівень безпеки, задоволеності та інформованості для пацієнта [17].

Основні $з$ них, з коротким описом наведені нижче.

Робототехніка - яка використовується для виконання хірургічних втручань і забезпечує покращену продуктивність, рух та контроль, зменшуючи тим самим травмування тканин. Він ці технології дають змогу хіргами працювати в середовищі, яке вважається небезпечним для них.

Голографія - це безконтактне тривимірне зображення, яке можна побачити неозброєним оком. Голограма може містити деталі анатомії людини, тканин, кісток та діяльності внутрішнього органу 3 високою роздільною здатністю. Це чудовий інструмент для безконтактного дослідження, який може використовуватись, наприклад, для вимірювання внутрішніх і зовнішніх переломів. У цифровому вигляді можна зберігати дані про хвороби пацієнтів та іншу інформацію, що може бути корисно для підготовки студентів-медиків.

Різноманітні датчики/сенсори знаходять широке застосування в медицині. Вони надають інформацію про температуру, артеріальний тиск та інші стани пацієнта. Можливість об'єднання пристроїв 3 датчиками/сенсорами в мережу створило передумови до появи наступної проривної технології - Інтернету речей.

Iнтернет речей (Internet of things, IoT) відкрив нові можливості в медицині. Він надає можливість за допомогою Інтернет технологій об'єднати у єдину систему медичні пристрої та збирати цінну інформацію, щоб контролювати життєві показники та покращувати процес лікування пацієнтів. Індустрія 4.0 або четверта промислова революція описує перетворення та розвиток промислового виробництва шляхом оцифрування нових технологій. Ідея промислової революції змінювалася 3 десятиліття на десятиліття; в даний час існує глобальна конкуренція між промисловими виробниками. У відповідь Індустрія 4.0 додала новий вимір, де за допомогою нових технологій промисловий ринок вийшов на новий рівень, подібного якому раніше не було. Концепція промислового Інтернету речей (Industrial Internet of Things, IIoT) була введена в 2012 році [18], являє собою тісно поєднані цифровий та фізичний світи, що межують з великими даними i 3 Інтернетом речей (IоT). Це визначення описує багато поширених уявлень про Індустрію 4.0. Експерти підрахували, що близько 46\% [19] світової економіки може отримати вигоду від промислового Інтернету.

Об'єкти, що складають ІоТ, представлені широким спектром різного обладнання $\mathrm{i}$ застосувань, включаючи RFID та бездротові сенсорні мережі, і всі вони мають визначений набір суворих вимог, наприклад. розмірів, енергоспоживання, можливостей обробки. Наприклад, бездротова мережа натільних пристроїв (wireless body area network, WBAN), що представляють особливий інтерес для охорони здоров'я, складається 3 бездротових пристроїв (сенсорів і актуаторів), прикріплених або імплантованих в організм людини [20]. Сфера охорони здоров'я виявилася однією 3 найпривабливіших сфер застосування IоT [21] Так прогрес у бездротових технологіях значною мірою допомагає у моніторингу фізіологічних параметрів у реальному часі, таким чином полегшуючи безперебійну допомогу при хронічних захворюваннях, роблячи можливою ранню діагностику та управління невідкладними медичними станами [21].

Дані зібрані за допомогою датчиків/сенсорів, ІоТ та інших джерел та технологій можуть оброблятися за допомогою технологій Великих даних (Big data), які допомагають отримати відповідну критичну інформацію щодо способів покращення догляду та методів лікування.

Також для аналізу медичних даних може використовуватись Штучний інтелект (Ш). ШI (Artificial intelligence, AI), що знайшов застосування у медицині, наприклад, для аналізу складних медичних даних. Він може бути корисним для персоналізованої медицини, процесів діагностики, визначення рівня захворювання, розробки ліків, моніторингу пацієнтів тощо.

Ще однією засадничою технологією Індустрії $4.0 €$ адитивне виробництво. Адитивне виробництво - це важлива інновація, яка 
надзвичайно корисна в медичній галузі. Вона використовує технології 3D-друку, 3Dсканування та відповідне програмне забезпечення для проектування та сканування. Це дає змогу виготовляти різні медичні або інші фізичні деталі шар за шаром із даних систем 3D CAD. У медичній сфері це найуспішніша технологія завдяки своїй гнучкості в проектуванні та виробництві, яка надає можливість виготовляти точні імплантати, інструменти та спеціальні пристрої для конкретного пацієнта відповідно до конкретних вимог.

\section{V. РОЛЬ САD/САМ В МЕДИЧНІЙ ГАЛУЗІ.}

Завдяки останнім досягненням як у CAD/CAM, так i в медичних технологіях, CAD/CAM знаходить все більш широке застосування в медичних додатках та пристроях. Зокрема, технології $\mathrm{CAD} / \mathrm{CAM}$ та 3D-друку використовуються в біомедичній інженерії, клінічній медицині, індивідуальних медичних імплантатах, тканинній інженерії, стоматології, штучних суглобах, роботизованій хірургії тощо

Медична техніка часто $\epsilon$ складною, 3 багатьма окремими компонентами, з'єднаними між собою для досягнення певної функції. Крім того, ці машини повинні бути спроектовані та сконструйовані дуже точно, оскільки недосконала конструкція може призвести до збою функціональних можливостей, які ці машини мають запропонувати. Принципові переваги $\mathrm{CAD}$ зробили його ідеальним рішенням для революції в дизайні медичних апаратів, таких як мікрочипи (microarrays), апарати MPT тощо. CAD/CAM технології дають можливість створювати моделі медичної техніки, які відповідають конкретним вимірам та вимогам, визначеним специфікаціями. До того моменту, коли продукт пройде фазу моделювання та буде побудований, результат повинен бути виключно точним, як і описано у початкових специфікаціях.

\subsection{CAD/CAM технології в хірургії}

За останнє десятиліття було зроблено чимало нових медичних досягнень, які завдячують своїй появі CAD/CAM технологіям. Так, наприклад, в хірургії партнерство, яке налагоджується між хірургами та комп'ютерно- інтегрованими технологіями дає їм змогу виконувати певні кваліфіковані завдання краще, ніж без допомоги CADICAM технологій.

Розглянемо такі напрямки:

1. Комп'ютерно-інтегрована (Computer-Integrated Surgery, CIS).

2. Ортопедичні операції або операчіï по заміні суглобів.

Computer-Integrated Surgery, CIS у свою чергу можна поділити на два напрямки:

- Хірургічний CAD/CAM;

- Хірургічний асистент.

Хірургічний $C A D / C A M$ забезпечує точну реєстрацію/фіксацію роботизованих хірургічних інструментів по відношенню до медичних зображень. Наприклад, медичні зображення пацієнта використовуються для адаптації хірургічних роботизованих рухів до пацієнта. Це зводить до мінімуму травми пацієнта, створює невеликі і точні розрізи і зводить до мінімуму час післяопераційного відновлення.

До інших значних переваг, які надаються комп'ютерно-інтегрованою хірургією, відноситься можливість відстежувати і коригувати рухи роботів, а також підтримувати сталість продуктивності.

CIS також дає можливість працювати в середовищах, які можуть бути не сприятливими для хірургів-людей, наприклад, на дні океану або у відкритому космосі.

Другий напрямок CIS - Хірургічний асистент (Surgical Assistant) , який надає технології CAD/CAM для роботи з хірургічними інструментами.

Через точність, що забезпечується технологією CAD/CAM, хірургу не потрібно турбуватися про тремтіння рук або про складні операції всередині тіла пацієнта. Ці типи хірургічних асистентів функціонують як “подовжувачі/розширювачі хірургів”, оскільки вони розширюють можливості хірурга.

Інший тип хірургічного помічника, який спирається на точність, що забезпечується технологією $\mathrm{CAD} / \mathrm{CAM}$, відповідає за такі функції, як ендоскопічне утримання та втягування.

Наступна проривна медична технологія, яка залежить від технології CAD/CAM, - це ортопедичні операчії або операчії по заміні суглобів. 
Технології CAD/CAM під час операцій 3 заміни суглоба допомагають належним чином встановити ортопедичні імплантати, а також точно розташувати імпланти відносно один одного та до кісток пацієнта.

Подібним чином точність CAD/CAM $\epsilon$ важливою для остеотомій (процедур різання та повторного складання кісток) та для хірургії хребта. Наприклад, операція на хребті часто вимагає встановлення гвинтів у хребцях в безпосередній близькості від спинного мозку, нервів та кровоносних судин. Без точності CAD/CAM помилка людини під час операції на хребті може спричинити параліч або смерть.

\section{2. Використання технології CAD/CAM в медичних пристроях}

Існує безліч медичних виробів, які працюють за технологією $\mathrm{CAD} / \mathrm{CAM}$. Перелічимо кілька відомих пристроїв та їх залежність від технології CAD/CAM.

Стоматологічні сканери використовують технологію $\mathrm{CAD} / \mathrm{CAM}$ для забезпечення точності фрезерування в кріслі (chairside milling), ортодонтії та імплантації. Завдяки точності, що забезпечується технологією CAD / CAM, хірурги-стоматологи вважають, що простіше створювати реставрації, не витрачаючи час і гроші на повторну зйомку, переробку і безліч коригувань.

Програмне забезпечення CAD використовується для допомоги рентгенологам 3 великим навантаженням. Наприклад, у мамографії програмне забезпечення CAD виділяє ділянки аномалій на зображеннях i передає інформацію лікарям та пацієнтам, що направляються.

Програмне забезпечення

$\mathrm{CAD}$ використовується для допомоги рентгенологам у виявленні переломів хребців та вузлів легенів на зображеннях грудної клітини. Технологія CAD/CAM незамінна для створення гнучких ендоскопічних систем.

3D-друк використовується для створення моделей травм та інших проблем зі здоров'ям. Ця здатність дозволяє лікарям розробити більш точний індивідуальний план лікування. Тривають дослідження щодо використання 3Dдруку для операцій з реконструкції обличчя, аневризми головного мозку, остеопорозу та переломів, пересадки шкіри та багатьох інших медичних нововведень. Це лише питання часу, коли ці нововведення стануть реальністю в медичній практиці.

\section{3. Використання технології CAD/CAM в діагностичних процедурах}

Існує багато медичних процедур, які залежать від технології CAD/CAM. У радіології комп'ютерне виявлення настільки важливе, що воно отримало абревіатуру CADx (комп'ютерна діагностика). Основна мета CADx - допомагати лікарям в інтерпретації медичних зображень. Велика кількість даних візуалізації генерується за допомогою рентгенівських променів, МРТ та ультразвукової діагностики, i для кількох рентгенологів неможливо проаналізувати та оцінити таку кількість зображень за короткий час. Хоча технологія CAD ніколи не може замінити досвід кваліфікованих лікарів, технологія $\mathrm{CAD}$ прискорює та забезпечує верифікаційні перевірки для діагностики можливих захворювань. Також програмне забезпечення CAD використовується для підтвердження огляду та інтерпретації, яку робить рентгенолог після огляду цифрової мамографії. Програмне забезпечення CAD здатне виявляти тонкі аномалії, які можуть бути пропущені навіть навченим оком лікаря. Програмне забезпечення CAD надає додаткову інтерпретацію, що дозволяє лікарю поставити збалансований і ретельний діагноз.

\section{VI. СУЧАСНІ ТЕНДЕНЦІЇ РОЗВИТКУ САD/САМ ТЕХНОЛОГІЙ В КОНТЕКСТІ ПЕРЕХОДУ ДО HЕALTHCARE 4.0}

CADICAM технології зазнали значних трансформацій з моменту своєї появи у 1960х. У 2015 році один 3 флагманів CAD індустрії, компанія Autodesk оголосила, що припинить продаж окремих ліцензій на користь моделі SaaS (Software as a Service, програмне забезпечення як сервіс). Така модель роботи базується на використанні хмарних технологій i пропонує взаємодіяти з додатками як з інтернетсервісами. У перший рік продажу продуктів використовуючи тільки модель SaaS, Autodesk зазнала збитків у майже півмільярда доларів, девальвувавши з 2,5 мільярда доларів до 1,95 мільярда доларів. Однак у 2017 році Autodesk знову почала набирати обертів і опублікувала величезний щорічний приріст, використовуючи модель $\mathrm{SaaS}$, тим самим зрушивши $\mathrm{CAD}$ індустрію в бік використання хмарних технологій. Пізніше було опубліковане велике 
дослідження ринку від відомої консалтингової компанії McKinsey [22], згідно з якими CAD індустрія на основі SaaS буде зростати на 35\% щорічно і становитиме майже $20 \%$ загального ринку CAD за п'ять років.

\section{1. Посилення впливу хмарних технологій}

Посилення впливу хмарних технологій стало важливою складовою переходу на засади Healthcare 4.0. Говорячи про хмарні технології насамперед мають на увазі організацію доступу до обчислювальних ресурсів через Інтернет для зберігання, агрегації, синтезу та пошуку, а також здатності впливати на дані за допомогою обчислювальних алгоритмів та програмних застосунків.

Хмарне виробництво (Cloud-based manufacturing, CBM) - це ще одна парадигма зростання, яка значно сприяє успіху парадигми 4.0. СВМ можна охарактеризувати як мережеву виробничу модель, яка використовує доступ на вимогу до спільної колекції різноманітних та розподілених виробничих ресурсів для формування тимчасових кіберфізичних виробничих ліній, які можуть бути налаштовані, що підвищує ефективність, зменшує витрати на життєвий цикл продукту та дозволяє оптимально розподіляти ресурси у відповідь на завдання клієнтів зі змінним попитом [23]. Відомо, що кожна людина унікальна, що викликає певні складності в медицині. Даний підхід якраз і покликаний вирішувати в тому числі і задачі задоволення індивідуальних потреб користувачів медичних послуг.

Очікується, що прогрес у хмарних технологіях у найближчі роки змінить також і процес автоматизованого проектування на краще. Хоча раніше CAD/CAM-застосунки використовувалися виключно на ПК, поява хмарних технологій дозволила зберігати життєво важливу інформацію на хмарних платформах, доступ до яких дизайнери та розробники можуть отримати 3 будь -якого місця в будь -який час. Хмарні технології не тільки збільшують обсяг доступної пам'яті, що використовується в CAD-системах, але також збільшує мобільність та значно спрощує впровадження оновлень.

Крім того, хмарні платформи дозволяють більшій кількості сторін переглядати та вносити зміни до проекту 3 інших пристроїв. У майбутньому ті, хто цікавляться розвитком
CAD/CAM технологій, побачать, що більша кількість виробничих підрозділів та потужностей буде працювати в «хмарі» та матиме доступ до відповідних прототипів. Розширений доступ, пропонований хмарними технологіями, сприяє покращенню співпраці та взаєморозумінню протягом усього процесу розробки, зменшуючи шанси на помилки та підвищуючи продуктивність, що є важливою складовою при створенні в тому числі i медичних виробів.

\section{2. Модельно-оріснтований підхід (Model- Based Definition (MBD))}

3 точки зору Національного інституту стандартизації і технологій США (National Institute of Standards and Technology, NIST) важливим кроком до переходу на засади Промисловості $4.0 €$ впровадження адитивного виробництва, яке включає в себе i 3Dмоделювання і 3D-друк. [24]. Даний підхід до виробництва широко використовує так званий модельно-орієнтований підхід (Model-Based Definition (MBD)), що значно спрощує використання альтернативних розробок, швидких прототипів, ремонтів, скорочення відходів та більш гнучких інновацій. Згідно [25] модельно-орієнтований підхід (MBD) грунтується на переході від звичайних 2Dкреслень до 3D-CAD-моделей як єдиного джерела визначення продукту, що охоплює всю інформацію про продукт і таким чином усуває потребу у 2D-зображенні. У роботі [26] зазначається, що MBD - це модель цифрового продукту, яка визначає вимоги та специфікації продукту. Підприємство на основі моделі (Model-Based Enterprise, MBE) використовує MBD для визначення вимог i специфікацій продукту замість паперових документів як джерела даних для всіх інженерних заходів протягом життєвого циклу продукту. Це також передбачає роботу 3 усіма внутрішніми та зовнішніми зацікавленими сторонами, які використовують дані про продукти, включаючи постачальників. Таким чином, у МВЕ моделі використовуються для керування всіма аспектами життєвого циклу продукту, і ці дані створюються лише один раз, а потім повторно використовуються для всіх подальших дій [27].

Використовуючи модельно-орієнтований підхід при створенні 3D-моделей у процесі CAD-проектування для визначення як вузлів 
виробу, так і окремих компонентів проекту можна значно підвищити ефективність процесу. 3D цифровий набір даних, пропонований MBD, дає змогу перевіряти та створювати продукт без необхідності 2D технічних креслень.

Традиційно в процесі автоматизованого проектування використовуються 2D технічні креслення для визначення таких показників, як інформація про процес, розміри та допуск моделі, тоді як 3D CAD-модель надає геометричну інформацію про продукт. Модельно-орієнтований підхід має багато переваг, які оцінять всі користувачі CADсистем. Часто 2D та 3D-проект може стати несинхронізованим, i, використовуючи лише 3D-модель, дизайнери можуть уникнути цього.

Модельно-орієнтований підхід дозволяє виробникам працювати безпосередньо в 3Dмоделі, що дає можливість чіткішої візуалізації та інтерпретації, а також покращує ступінь співпраці та послідовності між професіоналами у всьому процесі автоматизованого проектування. У майбутньому цілком ймовірно, що достоїнства 2D-проектів будуть все більше враховуватися (включатися) в модельноорієнтованому підході (MBD), зменшуючи необхідність 2D-проектів. У міру вдосконалення модельно-орієнтованого підходу, цілком ймовірно, що він стане стандартом у всій галузі.

\section{3. Штучний інтелект}

Однією 3 основних тенденцій розвитку CADICAM технологій, яка продовжує набирати популярність, є генеративне проектування. Генеративне проектування поєднує штучний інтелект (ШI, Artificial intelligence, AI) i машинне навчання (Machine Learning, ML) для створення незліченних варіантів проекту. Застосунки для генеративного проектування надають можливість користувачам надати програмному забезпеченню цілі проектування, а також такі параметри, як продуктивність, просторові вимоги, матеріали, методи виробництва та обмеження вартості. Далі програмне забезпечення досліджує всі можливі варіанти рішення та швидко створює альтернативи дизайну. За допомогою засобів штучного інтелекту перевіряється, що працює, а що ні, на кожній ітерації.

Використання машинного навчання $\mathrm{y}$ різних секторах зумовило одночасну співпрацю кільком взаємопов'язаними галузями $[28,29$, 30, 31, 32].

Переваги застосування штучного інтелекту в CAD/CAM системах:

- Скорочення часу, необхідного для розробки продукту;

- Покращення ефективності;

- Можливість створити більш точні та якісні конструкції;

- Штучний інтелект можна включити до автоматизованого проектування в процесі під назвою модельно-орієнтоване обгрунтування (Model-Based Reasoning), в якому Ш передбачає, як будуть взаємодіяти певні компоненти;

\section{- Штучний}

інтелект

можна

використовувати на ранніх стадіях розвитку для автоматизації певних функцій, вносячи необхідні зміни в конструкцію, не вимагаючи втручання людини;

- Штучний інтелект також можна використовувати для кількісного та якісного моделювання, аналізуючи ефективність продукту під час тестування;

- Завдяки використанню штучного інтелекту час, необхідний для виготовлення придатної конструкції, скоротиться, що призведе до підвищення ефективності та більших інновацій у всіх аспектах автоматизованого проектування.

Очікується, що вплив ШІ на охорону здоров'я з часом буде тільки зростати. Це багато в чому пов'язано з тими перевагами, які дані технології здатні забезпечити:

- Зменшення індивідуальних помилок лікарів;

- Зменшення помилок у виборі матеріалів техніками (зубними техніками);

- Зменшення негативного впливу 3-за відсутності достатньої інформації з однієї або обох сторін (лікар - пацієнт) під час лікування;

- Зменшення негативного впливу від упущення фактів (наприклад, симптоми, різні реакції на певні речовини, вживання алкоголю, сигарет тощо);

- Ймовірна наявність негативних етичних та моральних аспектів в спілкуванні між людьми (лікарями та пацієнтами), що робить неупередженість ШІ перевагою. 


\section{VII. ВИСНОВКИ}

Для вирішення поставленої задачі були проаналізовані вибіркові наукові дослідження та офіційні джерела методом сходження від абстрактного до конкретного та зроблені відповідні актуальні висновки. Використовуючи аксіоматичний метод, було констатовано, що застосування досягнень CAD/CAM технологій в медичній галузі веде до покращення в багатьох секторах охорони здоров'я, змінює спосіб надання традиційних послуг та продуктів та наближає галузь до відповідності парадигмі Healthcare 4.0. Такі технології контролюють стан здоров'я людини та сповіщають відповідних медичних працівників у надзвичайних випадках, щоб запропонувати оптимальну допомогу. CAD/CAM технології не тільки полегшили створення складної медичної техніки, а й допомагають в діагностиці та моніторингу здоров'я пацієнтів.

Індустрія 4.0 - це в першу чергу концепція переходу до цифрових, повністю автоматизованих середовищ i такий перехід вимагає нових підходів до проектування. Так процес створення інтелектуальних продуктів повинен передбачати можливість персоналізації продукту, можливість підтримки поточних оновлень та адаптації продукту до нових вимог, можливість прогнозувати та покращувати рішення, а також можливість дистанційної роботи. Дані підходи широко затребувані у медичній галузі.

Кожна людина унікальна, що викликає певні складності в медицині. Конкретні відмінності в розмірі, вазі, формі тощо можуть вимагати індивідуальних підходів до медичних процедур. Основні тенденції розвитку CAD/CAM технологій, такі як модельноорієнтований підхід, посилення впливу хмарних технологій, застосування штучного інтелекту сприяють покращенню співпраці та взаєморозумінню у багатьох процесах в медичній сфері, наприклад, таких як розробка i адаптація застосунків, зменшуючи шанси на помилки та підвищуючи продуктивність, що $\epsilon$ важливою складовою при створенні медичних виробів.

Технологія CAD/CAM зробила значний вплив на прогрес у медичній науці та практиці, особливо в медичній діагностиці та розробці медичних виробів:
- CADx став невід'ємною частиною клінічної практики, оскільки CADx зменшує кількість помилок спостережень;

- CADx підтверджує рішення лікарів, коли вони інтерпретують медичні зображення;

- CADx також зменшує хибнонегативні показники, коли лікарі інтерпретують медичні зображення.

У міру досягнення прогресу в діагностичній медицині вдосконалені алгоритми CADx будуть впроваджуватись в відповідне програмне забезпечення.

3D-друк став популярною технологією в стоматологічній практиці. Також ця технологія швидко впроваджується в засоби, які допоможуть лікарям у розробці покращених хірургічних процедур та планів лікування пацієнтів.

CAD/CAM відноситься до комп'ютерних технологій, що полегшують виробничий процес створення різних конструкцій.

Завдяки тому, що CAD/CAM забезпечує точні вимірювання та дозволяє проектантам створювати обгрунтовані 2D та 3D діаграми, автоматизоване проектування надзвичайно корисне як інструмент для розробки промислової продукції та моделювання функцій конструкцій до їх фізичного виготовлення.

Потенціал CAD як засобу підвищення ефективності та інновацій зростає, а останні тенденції галузі охорони здоров'я відображають вплив нових технологій у цій галузі.

Охорона здоров'я - сфера першочергового значення, до якої вкрай необхідне включення традиційних наукових галузей з інноваційними рішеннями. Наближення медичної галузі до парадигми Healthcare 4.0 можливе, в тому числі, за допомогою вдосконалення $\mathrm{CAD} / \mathrm{CAM}$ підходів та алгоритмів та розширюючи сфери застосування, тим самим досягаючи значних результатів в покращенні медичних послуг та підвищенні ефективності таких послуг, в тому числі і економічної.

Тому вбачаються доцільними подальші дослідження щодо збільшення сфер застосування CAD/CAM технологій та взагалі підходів парадигми Індустрії 4.0 в медичній галузі (Healthcare 4.0), наприклад, за рахунок розширення сфери застосування штучного інтелекту для покращення медичних послуг. 


\section{ПЕРЕЛІК ПОСИЛАНЬ}

1. Zhou, K., Liu, T., Zhou L. "Industry 4.0: Towards future industrial opportunities and challenges." In Fuzzy Systems and Knowledge Discovery (FSKD), 2015 12th International Conference on. IEEE, 2015. DOI:10.1109/FSKD.2015.7382284

2. Paul, S., Riffat, M., Yasir, A., Mahim, M.N., Sharnali, B.Y., Naheen, I.T., Rahman, A., Kulkarni, A. "Industry 4.0 Applications for Medical/Healthcare Services.” In J. Sens. Actuator Netw. 2021, 10, 43. https://doi.org/10.3390/jsan10030043

3. Lee, J. 'Smart health: Concepts and status of ubiquitous health with smartphone". In ICTC 2011. IEEE, 2011 DOI:10.1109/ICTC.2011.6082623

4. Park, J., Kim, M. "A study on the potential needs and market promotion of smart health in Korea". In 2013 International Conference on ICT Convergence (ICTC). IEEE, 2013. DOI:10.1109/ICTC.2013.6675489

5. Bamiah, M., Brohi, S., Chuprat, S., et al. "A study on significance of adopting cloud computing paradigm in healthcare sector". In 2012 International Conference on Cloud Computing Technologies, Applications and Management (ICCCTAM). IEEE, 2012. DOI:10.1109/ICCCTAM.2012.6488073

6. Aceto, G., Persico, V., Pescape, A. "A survey on information and communication technologies for industry 4.0: state of the art, taxonomies, perspectives, and challenges." IEEE Communications Surveys \& Tutorials, 2019. DOI:10.1109/COMST.2019.2938259

7. Aceto, G., Persico, V., Pescape, A. "Industry 4.0 and health: Internet of things, big data, and cloud computing for healthcare 4.0." In J. Ind. Inf. Integr. 2020, 18, 100129. https://doi.org/10.1016/j.jii.2020.100129

8. Jayaraman, P.P., Forkan, A.R.M., Morshed, A., Haghighi, P.D., Kang, Y.B. "Healthcare 4.0: A review of frontiers in digital health." In Wiley Interdiscip. Rev. Data Min. Knowl. Discov. 2020, 10, e1350 https://doi.org/10.1002/widm.1350

9. Tortorella, G.L., Fogliatto, F.S., Mac Cawley Vergara, A., R. Vassolo, Sawhney, R. "Healthcare 4.0: Trends, challenges and research directions." In Prod. Plan. Control. 2019, 31, 1245-1260. https://doi.org/10.1080/09537287.2019.1702226

10. Mobinizadeh, M., Doaee, Sh., Olyaeemanesh, A., Azadbakht, M., Nejati, M., Aboee P."Health Technology Assessment of CAD/CAM in Dentistry." In The International Journal of Travel Medicine and Global Health, V.2, Issue 2, Spring 2014, p. 81-85

11 Wolf, B., Scholze, Ch. "Medicine 4.0" The role of electronics, information technology and microsystems in modern medicine.” In Current Directions in Biomedical Engineering 2017; 3(2): 183-186. https://doi.org/10.1515/cdbme-2017-0038

12. Javaid, M., Haleem, A. "Industry 4.0 applications in medical field: A brief review." In Current Medicine Research and Practice Volume 9, Issue 3, May-June 2019, Pages 102-109. DOI: 10.1016/j.cmrp.2019.04.001

13. Omanovic-Miklicanin, E., Maksimovic, M., Vujovic, V. "The future of healthcare: Nanomedicine and internet of nano things." In Folia Medica Facultatis Medicinae Universitatis Saraeviensis, 50(1), 2015.

14. Aceto, G., Persico, V., Pescape, A. "The role of information and communication' technologies in healthcare: taxonomies, perspectives, and challenges." In Journal of Network and Computer Applications, 107, 2018. DOI:10.1016/j.jnca.2018.02.008

15. Javaid, M., Haleem, A. "Industry 4.0 applications in medical field: A brief review." Article in Current Medicine Research and PracticeApril 2019 DOI: 10.1016/j.cmrp.2019.04.001

16. Raghupathi, W., Raghupathi, V."Big data analytics in healthcare: promise and potential." In Health Information Science and Systems 2(1), 2014. doi: 10.1186/2047-2501-2-3

17. Thuemmler, C., Ba, C. "Health 4.0: Application of Industry 4.0 Design Principles in. Future Asthma Management." In: How
Virtualization and Big Data are Revolutionizing. Healthcare. 2017:23e37. DOI:10.1007/978-3-319-47617-9_2

18. Boyes, H., Hallaq, B., Cunningham, J., Watson, T."The industrial internet of things (IIOT): An analysis framework." In Comput. Ind. 2018, 101, 1-12. https://doi.org/10.1016/j.compind.2018.04.015

19. Lasi, H., Fettke, P., Kemper, HG., et al. "Industry 4.0." Bus Inf Syst Eng 6, 239-242 (2014). https://doi.org/10.1007/s12599-0140334-4

20. Chen, M., Gonzalez, S., Vasilakos, A., Cao, H., Leung, V. C. "Body area networks: A survey." In Mobile networks and applications, 16(2), 2011. DOI:10.1007/S11036-010-0260-8

21. Botta, A., de Donato, W., Persico, V., Pescape, A. "Integration of cloud computing and internet of things: A survey." In Future Generation Comp. Syst., 2016. https://doi.org/10.1016/j.future.2015.09.021

22. Heppelmann and Hirschtick on PTC's Acquisition of Onshape. Oct 24, 2019

https://www.worldcadaccess.com/blog/2019/10/heppelmann-andhirschtick-on-ptcs-acquisition-of-onshape.html Доступ 21.10.2021

23. Wu, D., Greer, MJ., Rosen, DW., Schaefer, D. "Cloud manufacturing: strategic vision and state-of-the-art." In Journal of $\begin{array}{llll}\text { Manufacturing } & \text { Systems, } 2013 . & 32(4), & \text { 564- }\end{array}$ 579. https://doi.org/10.1016/j.jmsy.2013.04.008

24. MEP National Network ${ }^{\mathrm{TM}}$. Advanced Manufacturing Technology Services/Industry $\quad 4.0 \quad \mathrm{https}: / / \mathrm{www}$. nist.gov/mep/advancedmanufacturing-technology-servicesindustry-40 Доступ 21.10.2021

25. Quintana, V., Rivest, L., Pellerin, R. et al. "Will model-based definition replace engineering drawings throughout the product lifecycle? A global perspective from aerospace industry." In Comput Ind 2010;

https://doi.org/10.1016/j.compind.2010.01.005

26. Alemanni, M., Destefanis, F., Vezzetti, E. "Model-based definition design in the product lifecycle management scenario." Int J Adv Manuf Technol 2011; 52: 1-14. https://doi.org/10.1007/s00170-010-2699-y

27. Hedberg, T., Lubell, J., Fischer, L. et al. "Testing the digital thread in support of model-based manufacturing and inspection." $\mathrm{J}$ Comput Inf Sci Eng 2016; 16: 021001. https://doi.org/10.1115/1.4032697

28. Sunny, M.R., Kabir, M.A., Naheen, I.T., Ahad, M.T. "Residential Energy Management: A Machine Learning Perspective." In Proceedings of the 2020 IEEE Green Technologies Conference (GreenTech), Oklahoma City, OK, USA, 1-3 April 2020; pp. 229234. DOI:10.1109/GreenTech46478.2020.9289737

29. Paul, S., Ni, Z., Mu, C. "A Learning-Based Solution for an Adversarial Repeated Game in Cyber-Physical Power Systems." IEEE Trans. Neural Netw. Learn. Syst. 2020, 31, 4512-4523. DOI: 10.1109/TNNLS.2019.2955857

30. Dengler, S., Lahriri, S., Trunzer, E., Vogel-Heuser, B. “Applied machine learning for a zerodefect tolerance system in the automated assembly of pharmaceutical devices (DECSUP-D-20-00799R1)." $\begin{array}{llll}\text { Decis. Support } & \text { Syst. 2021, 146, } 113540 .\end{array}$ https://doi.org/10.1016/j.dss.2021.113540

31. Paul, S., Ni, Z. "A Multistage Game in Smart Grid Security: A Reinforcement Learning Solution.” IEEE Trans. Neural Netw. Learn. Syst. 2019, 30, 2684-2695. 10.1109/TNNLS.2018.2885530

32. Dal Mas, F., Piccolo, D., Cobianchi, L., Edvinsson, L., Presch, G., Massaro, M., Skrap, M., et. al."The effects of artificial intelligence, robotics, and industry 4.0 technologies. Insights from the Healthcare sector." In Proceedings of the First European Conference on the Impact of Artificial Intelligence and Robotics, Oxford, UK, 31 October-1 November 2019. DOI:10.34190/ECIAIR.19.015 


\title{
РОЛЬ ТЕХНОЛОГИЙ АВТОМАТИЗИРОВАННОГО ПРОЕКТИРОВАНИЯ И ПРОИЗВОДСТВА ВО ВНЕДРЕНИИ ПОДХОДОВ ИНДУСТРИИ 4.0 В СФЕРЕ ЗДРАВООХРАНЕНИЯ
}

\author{
Рудницкая Е. В. доцент, $\mathrm{PhD}$ \\ olena.rudnitska@gmail.com \\ Кафедра биомедицинской инженерии \\ Национального технического университета Украины \\ "Киевский политехнический институт имени Игоря Сикорского", \\ м. Киев, Украина
}

\begin{abstract}
Реферат - Данная работа рассматривает способы применения САD САМ технологий в сфере здравоохранения на пути к переходу на приниипь парадигмы Healthcare 4.0. Данные технологии позволяют добиваться значительных результатов в улучшении медицинских услуг, а также проектировании и изготовлении изделий медичинского назначения. Для этого проанализирована роль парадигмы Индустрия 4.0 в сфере развития системі здравоохранения, роль САD САМ технологий в медицинской отрасли и обозначены основные тенденции развития САD/САМ технологий в контексте перехода к Неаlthcare 4.0. При анализе роли парадигмы Индустрия 4.0 были выделены основные группы технологий, являющихся движущими силами этой концепции, и кратко описаны технологии, способные повысить уровень безопасности, удовлетворенности и информированности для пациента: робототехника, голография, датчики/сенсоры, интернет вещей и промышленный интернет вещей, большие данные, искусственный интеллект и аддитивное производство. При исследовании роли САD САМ технологий в области медицины было проанализировано применение этих технологий в (а) хирургии и рассмотрены направления компьютерно-интегрированной хирургии (хирургический CAD/САМ и хирургический ассистент) и ортопедические операции или операции по замене суставов; (б) использование технологии CAD/САМ в медицинских устройствах; (в) использование технологии САD/САМ в диагностических прочедурах. Далее показан потенциал CAD как способа повышения эффективности и внедрения инноваций. При анализе современных тенденций развития CAD/CAM технологий в контексте перехода к парадигме Неаlthcare 4.0, были выделены и описаны следующие аспекты: (1) усиление влияния облачных технологий и преимущества, которые они оказывают; (2) модельно-ориентированный подход и особенности его применения при автоматизированном проектировании; (3) генеративное проектирование с использованием технологий искусственного интеллекта. Представлены преимущества применения искусственного интеллекта в процессе проектирования и изготовления необходимых для медицинской отрасли продуктов и его возможсное влияние на отрасль в иелом.

Выводы: Технология CAD/CAM оказала значительное влияние на прогресс в медицинкой науке и практике. Потенциал САD как средства повышения эффективности и инноваций растет, а последние тенденции в области здравоохранения отражают влияние новых технологий в этой области. Здравоохранение - сфера первостепенного значения, в которую крайне необходимо включение традииионных научных отраслей с инновачионными решениями. Приближение медииинской отрасли к nарадигме Неаlthсаге 4.0 возможно, в том числе посредством совершенствования САD/САМ подходов и алгоритмов, а также расширения сфер применения, тем самым достигая значительных результатов в улучшении медицинских услуг и повышении эффективности таких услуг, в том числе и экономической. Поэтому сделаны выводы о иелесообразности дальнейших исследований по расширению сфер применения CAD/САМ технологий и вообще подходов парадигмы Индустрии 4.0 в медицинской отрасли (Hеalthcare 4.0).
\end{abstract}

Ключевые слова: САD\САМ, Индустрия 4.0, Hеalthcare 4.0, искусственный интеллект, облачные технологии, аддитивное производство 


\section{THE COMPUTER-AIDED DESIGN AND PRODUCTION TECHNOLOGIES ROLE IN THE IMPLEMENTATION OF INDUSTRY 4.0 APPROACHES IN THE HEALTHCARE FIELD}

Rudnitska O.V. Associate Professor, $\mathrm{PhD}$ of Technical Sciences olena.rudnitska@gmail.com Department of Biomedical Engineering National Technical University of Ukraine "Igor Sikorsky Kyiv Polytechnic Institute", Kyiv, Ukraine

Abstract - This paper explores how CAD/CAM technologies can be applied in healthcare on the transition path to the Healthcare 4.0 paradigm. These technologies allow us to achieve significant results in the medical services improvement, as well as the design and manufacture of medical products. For this, the role of the Industry 4.0 paradigm in the development of health care systems, the role of CAD $\backslash C A M$ technologies in the medical industry has been analyzed and the main trends in the development of CAD / CAM technologies in the context of the transition to Healthcare 4.0 are analyzed. When analyzing the role of the Industry 4.0 paradigm, the main groups of technologies that are the driving forces of this concept were identified, and technologies that can increase the level of safety, satisfaction and awareness for the patient were briefly described: robotics, holography, sensors / sensors, the Internet of Things and the Industrial Internet of Things, Big data, Artificial Intelligence and Additive manufacturing. When studying the role of CAD $\backslash C A M$ technologies in the field of medicine, the application of these technologies was analyzed, specifically: (a) Computer-Integrated Surgery (Surgical CAD/CAM and Surgical Assistant) and Orthopedic or Joint Replacement Operations; (b) the use of CAD/CAM technology in medical devices; (c) the use of CAD/CAM technology in diagnostic procedures. Further shows the potential of CAD as a way to improve efficiency and drive innovation. When analyzing modern trends in the development of CAD/CAM technologies in the context of the transition to the Healthcare 4.0 paradigm, the following aspects were identified and described: (1) the increasing impact of cloud technologies and the benefits they provide; (2) model-based approach and features of its application in computer-aided design; (3) generative design using artificial intelligence technologies.

Conclusions: CAD / CAM technology has had a significant impact on progress in medical science and practice. The potential of CAD as a way to improve efficiency and innovation is growing, and recent trends in healthcare reflect the impact of new technologies in this area. Healthcare is a high-priority area where the inclusion of traditional scientific industries with innovative solutions is imperative. The oncoming of the medical industry to the Healthcare 4.0 paradigm is possible, also through the improvement of CAD/CAM approaches and algorithms, as well as the expansion of application areas, thereby achieving significant results in improving medical services and increasing the efficiency of such services, including economic. Therefore, conclusions were made about the feasibility of further research to expand the scope of CAD/CAM technologies and, in general, the approaches of the Industry 4.0 paradigm in the medical industry (Healthcare 4.0).

Keywords: CAD\CAM, Industry 4.0, Healthcare 4.0, artificial intelligence, cloud technologies, additive manufacturing 